\title{
HEATS OF K/CA AND K/PB EXCHANGE IN TWO TROPICAL SOILS AS MEASURED BY FLOW CALORIMETRY1
}

\author{
Chip Appel ${ }^{2}$, Dean Rhue ${ }^{3}$, Lena $\mathrm{Ma}^{3}$, and Bill Reve ${ }^{3}$
}

\begin{abstract}
Flow calorimetry can provide useful information about surface chemical reactions in soils that cannot be obtained readily by other methods. When flow calorimetry is conducted over a range of surface coverages, different sorption heats can be calculated to yield information about how binding energies vary with coverage, i.e., surface heterogeneity. The purpose of this study was to determine heats of exchange for $\mathrm{K} / \mathrm{Ca}$ and $\mathrm{K} / \mathrm{Pb}$ systems using flow calorimetry and to evaluate the degree of surface heterogeneity with respect to cation exchange. Surface horizon samples from a Typic Acrorthox and Typic Tropohumult from Puerto Rico were used. Lead was adsorbed specifically in both soils, but no adsorption heat was detected for this reaction in either soil. However, heats associated with reversible cation exchange between $\mathrm{K}$ and $\mathrm{Pb}$ were observed. Heats for $\mathrm{K} / \mathrm{Ca}$ exchange were greater than those generated for $\mathrm{K} / \mathrm{Pb}$ exchange in both soils. Heats of exchange were greater in the U1tisol than in the Oxisol. The differential heats of exchange were independent of exchange composition for both $\mathrm{K} / \mathrm{Pb}$ and $\mathrm{K} / \mathrm{Ca}$ exchange in the Oxisol, indicating that all cation exchange sites were similar energetically. In the Ultisol, the differential heats of exchange increased as exchangeable $\mathrm{K}$ decreased, indicating that the exchange sites were not similar energetically. These differences were attributed to the presence of smectite in the Ultisol, which was able, in part, to collapse when saturated with $K$. (Soil Science 2002;167:773-781)
\end{abstract}

Key words: Enthalpy, ion-exchange, surface heterogeneity.

$\mathbf{F}$ LOW calorimetry provides a direct and quan titative measure of the heat of a reaction at a soil surface (Rhue et al., 2002). Coupled with other macroscopic and spectroscopic techniques, flow calorimetry can provide useful information about surface chemical reactions in soils that can not readily be obtained by other methods. For ex ample, flow calorimetry combined with measure

'Florida Agricultural Experiment Station Journal Series No. R-08910.

2Earth and Soil Sciences Department, Cal Poly, San Luis Obispo, CA 93407. Dr. Appel is correspondins author. E-mail: cappel@calpoly.edu

Soil and Water Science Dept., University of Florida, Gainesville, FL 32605.

Received March 27, 2002; accepted Aus. 22, 2002.

DOI: 10.1097/01.ss.0000043037.84859.d1 ments of surface coverage can yield information about how binding energies vary with saturation of reactive surface sites, i.e., surface heterogeneity. Thus, different types of exchange/sorption sites may be identified within a heterogeneous struc ture such as soil (Goulding, 1983).

To our knowledge, no research has measured the surface heterogeneity of soils using flow cal orimetry, nor has anyone studied $\mathrm{K} / \mathrm{Pb}$ and $\mathrm{K} / \mathrm{Ca}$ systems using this technique. Lead was chosen because it is an important cationic con taminant in soils worldwide (Brown et al., 1999; Nriagu, 1998) and is known to undergo both specific and nonspecific adsorption reactions in soil. Calcium, on the other hand, does not adsorb specifically to soil surfaces and is commonly found in high relative concentrations on soil 
cation exchange sites (McBride, 1994; Sparks, 1995). Specific objectives of this study were (i) to measure integral heats of adsorption associated with $\mathrm{K} / \mathrm{Ca}$ and $\mathrm{K} / \mathrm{Pb}$ exchange using flow calo rimetry and (ii) to derive information about the heterogeneity of cation exchange sites in these soils from the differential heats of adsorption.

\section{METHODS AND MATERIALS}

The surface horizons $(0-15 \mathrm{~cm})$ of two trop ical soils from Puerto Rico were sampled be tween 1996 and 1998, air dried, and sieved to ob tain aggregates between 0.25 and $0.50 \mathrm{~mm}$. An Oxisol (clayey, oxidic, isohyperthermic Typic Acrorthox), sampled near Mayaguez on the west coast, and an Ultisol (clayey, mixed, isohyperther mic Typic Tropohumult), taken from the central mountainous area near Corozal, were used. Trop ical soils were selected for study because, relative to their temperate region counterparts, much less is known about $\mathrm{K} / \mathrm{Ca}$ and $\mathrm{K} / \mathrm{Pb}$ exchange in these systems. Mineralogical and chemical prop erties of these soils reported by Appel and $\mathrm{Ma}$ (2002) are shown in Table 1.

\section{Flow Calorimetry}

The operation of the flow calorimeter has been described in a previous paper (Rhue et al., 2002). Approximately $50 \mathrm{mg}$ of soil were placed inside a small column, and solutions containing $\mathrm{K}$, $\mathrm{Ca}$, or $\mathrm{Pb}$ as nitrates were forced through the col umn using a total pressure drop of about $100 \mathrm{~cm}$ of water. Flow rates were controlled with a preci sion needle valve at the outlet side of the calorime ter and were generally in the range of 0.25 to 0.35 $\mathrm{mL} \min ^{-1}$. A pair of thermistors, one upstream and the other downstream from the soil column, formed one half of an electronic bridge and sensed temperature changes in the solution as it passed through the column. A change in solution temperature produced a differential output voltage from the bridge. This differential voltage was fed into an instrumentation amplifier, and the ampli fied signal was fed into a computer for processing.
Obtaining Integral Heats of Adsorption

The ionic strength $(I)$ and $\mathrm{pH}$ of each solu tion were $15 \mathrm{mM}$ and 4.7 , respectively. Changes in soil solution $\mathrm{pH}$ and $I$ can lead to changes in the surface charge of variably charged soil col loids and, thus, changes in cation sorption in these systems (Uehara and Gillman, 1981; van Olphen, 1977).

Approximately $50 \mathrm{mg}$ of soil were placed in the calorimeter and equilibrated with $15 \mathrm{mM}$ $\mathrm{KNO}_{3}$ until a steady baseline was obtained. The input solution was then changed to $5 \mathrm{mM}$ $\mathrm{Ca}\left(\mathrm{NO}_{3}\right)_{2}$, which resulted in an endothermic heat of exchange as $\mathrm{Ca}$ displaced exchangeable $\mathrm{K}$. When the signal had returned to baseline, the solution was changed back to $\mathrm{KNO}_{3}$, and the exothermic peak associated with the displace ment of exchangeable $\mathrm{Ca}$ by $\mathrm{K}$ was recorded. Several K/Ca exchange cycles were recorded. The $\mathrm{K}$ and $\mathrm{Ca}$ peak areas were of equal and op posite magnitude, which was indicative of a re versible process.

Following the last $15 \mathrm{mM} \mathrm{KNO}_{3}$ wash, the solution was changed to $5 \mathrm{mM} \mathrm{Pb}\left(\mathrm{NO}_{3}\right)_{2}$, and several $\mathrm{K} / \mathrm{Pb}$ cycles were recorded as was done with $\mathrm{K} / \mathrm{Ca}$. After the last $\mathrm{K} / \mathrm{Pb}$ cycle, several $\mathrm{K} / \mathrm{Ca}$ cycles were repeated to determine if $\mathrm{Pb}$ treatment had affected changes in the heat of $\mathrm{K} / \mathrm{Ca}$ exchange. After the last $\mathrm{K} / \mathrm{Ca}$ cycle, the soil was removed from the calorimeter and ana lyzed for total $\mathrm{Pb}$ by digesting it in concentrated $\mathrm{HNO}_{3}$ according to U.S. Environmental Protec tion Agency Method 3051 (USEPA, 1996). Lead extracted by this method was taken as a measure of specifically adsorbed $\mathrm{Pb}$. The native soil $\mathrm{Pb}$ concentrations were 10 and $8 \mathrm{mg} \mathrm{kg}^{-1}$ for the Oxisol and Ultisol, respectively, and were not used to correct values for specific adsorption.

Obtaining Differential Heats of Adsorption

Approximately $50 \mathrm{mg}$ of soil were placed in the calorimeter and equilibrated with $15 \mathrm{mM}$ $\mathrm{KNO}_{3}$. When a baseline was obtained, the solu tion was changed to one containing both $\mathrm{K}^{+}$and

TABLE 1

Physiochemical properties of soil (Appel and Ma, 2002)

\begin{tabular}{|c|c|c|c|c|c|c|c|c|c|}
\hline Sample & $\begin{array}{l}\text { Organic } \\
\text { matter } \\
\mathrm{g} \mathrm{kg}^{-1}\end{array}$ & PZNC & $\mathrm{pH}$ & $\begin{array}{c}\mathrm{CEC} \\
\mathrm{mmol}_{\mathrm{c}} \mathrm{kg}^{-1}\end{array}$ & $\begin{array}{c}\text { Sum } \\
\mathrm{H}+\mathrm{Al} \\
\mathrm{mmol}_{\mathrm{c}} \mathrm{kg}^{-1}\end{array}$ & $\begin{array}{c}\text { Total } \\
\mathrm{Fe}+\mathrm{Al} \\
\mathrm{g} \mathrm{kg}^{-1}\end{array}$ & $\begin{array}{c}\text { Clay } \\
\text { mineralogy }{ }^{1}\end{array}$ & $\begin{array}{l}\text { Texture }^{2} \\
\mathrm{~g} \mathrm{~kg}^{-1}\end{array}$ & $\begin{array}{c}\text { Specific } \\
\text { surface } \\
\text { area } \mathrm{m}^{2} \mathrm{~g}^{-1}\end{array}$ \\
\hline Oxisol & 41 & 3.7 & 4.9 & 31 & 17 & 287 & $\mathrm{k}>\mathrm{go}>\mathrm{gi}=\mathrm{q}$ & $100-340-560$ & 41.9 \\
\hline Ultisol & 19 & 2.3 & 4.7 & 110 & 71 & 86 & $\mathrm{k}>\mathrm{q}>\mathrm{s}>\mathrm{go}>\mathrm{m}$ & $120-290-590$ & 37.8 \\
\hline
\end{tabular}

${ }^{1} \mathrm{k}=$ kaolinite; $\mathrm{gi}=$ gibbsite; $\mathrm{go}=$ goethite $\mathrm{s}=$ smectite $; \mathrm{q}=$ quartz; $\mathrm{m}=$ mica.

${ }^{2}$ sand - silt - clay. 
$\mathrm{M}^{2+}\left(\mathrm{M}^{2+}=\mathrm{Ca}^{2+}\right.$ or $\left.\mathrm{Pb}^{2+}\right)$ while keeping $I$ constant at $15 \mathrm{mM}$ and $\mathrm{pH}$ at 4.7. The solution compositions were as follows: $15 \mathrm{mM} \mathrm{KNO}$, $14.25 \mathrm{mM} \mathrm{KNO}{ }_{3}+0.25 \mathrm{mM} \mathrm{M}\left(\mathrm{NO}_{3}\right)_{2}, 13.5$ $\mathrm{mMKNO}_{3}+0.5 \mathrm{mMM}\left(\mathrm{NO}_{3}\right)_{2}, 12 \mathrm{mMKNO}_{3}$ $+1.0 \mathrm{mM} \mathrm{M}\left(\mathrm{NO}_{3}\right)_{2}, 9 \mathrm{mM} \mathrm{KNO}_{3}+2 \mathrm{mM}$ $\mathrm{M}\left(\mathrm{NO}_{3}\right)_{2}, 6 \mathrm{mM} \mathrm{KNO}_{3}+3 \mathrm{mM} \mathrm{M}\left(\mathrm{NO}_{3}\right)_{2}, 3$ $\mathrm{m} M \mathrm{KNO}_{3}+4 \mathrm{~m} M \mathrm{M}\left(\mathrm{NO}_{3}\right)_{2}$, and $5 \mathrm{~m} M$ $\mathrm{M}\left(\mathrm{NO}_{3}\right)_{2}$. Several cycles of heat measurements were obtained for each solution composition. The measured heats were plotted against the ex changeable divalent cation concentration and a smooth curve fitted through the data using a least squares procedure. The differential heat of ex change was obtained by differentiating this rela tionship with respect to exchangeable divalent cation concentration.

The concentrations of exchangeable cations corresponding to the above $\mathrm{K}^{+}+\mathrm{M}^{2+}$ solutions were measured in a separate procedure. Five grams of soil were placed in $1.5 \mathrm{~cm}$ diameter columns (two replicates) and the exchange sites were ini tially saturated with $\mathrm{K}^{+}$using $15 \mathrm{mM} \mathrm{KNO}_{3}$ (ap proximately 20 pore volumes). The columns were then drained under suction $(20 \mathrm{~cm})$ and weighed in order to correct for any residual nitrate salts left in the soil. The soil was then flushed five times us ing $5 \mathrm{~mL}$ of $0.5 \mathrm{M} \mathrm{Mg}\left(\mathrm{ClO}_{4}\right)_{2}$. The effluent was collected and refrigerated prior to analysis by flame atomic absorption spectrophotometry. Pre liminary experiments indicated this amount of $\mathrm{Mg}\left(\mathrm{ClO}_{4}\right)_{2}$ desorbed all exchangeable cations sat isfactorily. Following the last $\mathrm{Mg}\left(\mathrm{ClO}_{4}\right)_{2}$ extrac tion, the column was flushed with 20 pore vol umes of $0.5 \mathrm{MNO}_{3}$, followed by 20 pore volumes of $15 \mathrm{mM} \mathrm{KNO}_{3}$ to ensure that the soil was $\mathrm{K}$ saturated, and equilibrated at $I=15 \mathrm{mM}$, $\mathrm{pH} 4.7$, before the next set of exchangeable cation measurements.

The soil was then saturated using one of the $\mathrm{K}^{+}+\mathrm{M}^{2+}$ solutions, starting with the lowest $\mathrm{M}^{2+}$ concentration and proceeding to the high est, each time extracting with $\mathrm{Mg}\left(\mathrm{ClO}_{4}\right)_{2}$ and re saturating with $\mathrm{KNO}_{3}$ before proceeding with the next concentration step. The columns were flushed with $\mathrm{K}^{+}+\mathrm{M}^{2+}$ solutions until the diva lent cation concentrations in the column effluent were essentially the same as that in the input so lution, which required as many as 100 pore vol umes. Duplicate values of exchangeable cation concentration at each concentration step were averaged and standard deviations calculated.

Following the last $\mathrm{Mg}\left(\mathrm{ClO}_{4}\right)_{2}$ extraction of the $\mathrm{Pb}$ treated columns, the soil was removed from the column and analyzed for total $\mathrm{Pb}$ by di gesting it in concentrated $\mathrm{HNO}_{3}$ according to USEPA Method 3051 (USEPA, 1996). This total $\mathrm{Pb}$ concentration was taken as a measure of specif ically adsorbed $\mathrm{Pb}$.

\section{RESULTS AND DISCUSSION}

Integral Heats of Adsorption

Because $\mathrm{Pb}$ is able to readily undergo specific adsorption reactions in a variety of soils, organic matter, and pure minerals (Bargar et al., 1998; Davis and Leckie, 1978; Eick et al., 1999; Pardo, 2000; Phillips, 1999; Strawn et al., 1998; Strawn and Sparks, 1999; Xia et al., 1997; Zhang et al., 1997), it was important to partition the calori metric heat of sorption between reversible ion ex change and specific adsorption. The specific ad sorption of $\mathrm{Pb}$ has been attributed to: (i) the relatively high affinity of $\mathrm{Pb}$ for most functional groups in organic matter, which are hard Lewis bases carboxylic and phenolic groups $\left(\mathrm{Pb}^{2+}\right.$ is a borderline hard Lewis acid); (ii) its electronegativ ity (2.10), enabling it to pull electron density away from soil surface functional groups during bond formation; and (iii) the relatively low $\mathrm{pK}_{\mathrm{H}}$ (nega tive $\log$ of hydrolysis constant, 7.78) of $\mathrm{Pb}$, which allows it to form chemical bonds with soil surfaces in hydrolyzed form (Bruemmer et al., 1986; Forbes et al., 1976; Huheey, 1983; McBride, 1994). In this study, sorbed $\mathrm{Pb}$ that was not ex changeable with a neutral salt such as $\mathrm{Mg}\left(\mathrm{ClO}_{4}\right)_{2}$ or $\mathrm{KNO}_{3}$ was assumed to be specifically adsorbed. Specific adsorption is the proposed mechanism because speciation calculations performed by Vi sual Minteq (Gustafsson, 2002) showed that solu tions were undersaturated with respect to solid phase $\mathrm{Pb}(\mathrm{OH})_{2}$ and $\mathrm{Pb}\left(\mathrm{CO}_{3}\right)_{2}$.

The Oxisol soil specifically adsorbed 3000 to $3500 \mathrm{mg} \mathrm{kg}^{-1} \mathrm{~Pb}$, whereas the Ultisol specifically adsorbed $1900 \mathrm{mg} \mathrm{kg}^{-1}$ (Table 2). The Oxisol had a greater abundance of both organic matter (4.1\% and $1.9 \%$ for the Oxisol and Ultisol, re

TABLE 2

Nonexchangeable $\mathrm{Pb}$ in column adsorption versus calorimeter studies

\begin{tabular}{lll}
\hline \multirow{2}{*}{ Soil } & Adsorption study & \multicolumn{1}{c}{ Calorimeter study } \\
\cline { 2 - 3 } & \multicolumn{1}{c}{} & \\
\hline Oxisol & $2975(694) \mathrm{a}^{1,2}$ & $\mathrm{mg} \mathrm{kg}^{-1}$ \\
Ultisol & $1848(472) \mathrm{b}$ & $1891(764) \mathrm{b}$ \\
\hline
\end{tabular}

${ }^{1}$ Numbers in parenthesis are standard deviations of the means.

${ }^{2}$ Means within a column or row with the same letter are not significantly different at $p<0.05$. 
spectively) and iron/aluminum oxides (28.7\% and $8.6 \%$ for the Oxisol and Ultisol, respectively) compared with the Ultisol (Table 1). These com ponents probably accounted for the greater spe cific adsorption of $\mathrm{Pb}$ in the Oxisol as both ma terials have been shown to be important in the specific adsorption of heavy metals, especially $\mathrm{Pb}$ (Bargar et al., 1997a and b; Gao et al., 1997; Gong and Donahoe, 1997; Jenne, 1968; Kinniburgh et al., 1976; Sauve et al., 1998, 2000).

Flow calorimetry allows multiple sorption/ desorption cycles to be applied to the same sam ple, enabling reversible and irreversible processes to be distinguished (Rhue et al., 2002). For all soil samples subjected to $\mathrm{Pb}$ solutions during the cal orimetry experiments, there were no significant differences between the heats of $\mathrm{Pb}$ sorption and desorption, and there were no significant changes in the heats associated with repetitive $\mathrm{Pb}$ sorp tion/desorption cycles. Thus, we conclude that the only reaction detectable calorimetrically was that associated with reversible $\mathrm{K} / \mathrm{Pb}$ cation ex change. Since specific adsorption of $\mathrm{Pb}$ on these soils did not result in a detectable heat signal and was, therefore, a very low energy reaction, we also conclude that the driving force for the specific adsorption of $\mathrm{Pb}$ was predominantly entropic (i.e., driven by a positive $\Delta \mathrm{S}$ ). The loss of $\mathrm{Pb}$ from the solution phase and its replacement by $\mathrm{H}^{+}$, $\mathrm{OH}^{-}$, and/or $\mathrm{H}_{2} \mathrm{O}$ would result in an increase in entropy. Entropic reactions have been observed by others studying heterovalent cation adsorption in soils (Gast et al., 1969; Laudelot et al., 1968; Maes and Cremers, 1977; Sparks and Jardine, 1981).

Heat amounts associated with $\mathrm{K} / \mathrm{Ca}$ exchange on soils before and after the specific adsorption of $\mathrm{Pb}$ were not significantly different. The specific adsorption of $\mathrm{Pb}$ must have occurred on sites other than cation exchange sites because the spe cific adsorption of $\mathrm{Pb}$ did not change the ener getics of $\mathrm{K} / \mathrm{Ca}$ exchange, nor did it change the CEC of our soils.

Table 3 shows the heats of $\mathrm{K} / \mathrm{Ca}$ and $\mathrm{K} / \mathrm{Pb}$ exchange, measured by flow calorimetry in the Oxisol and Ultisol. The adsorption of $\mathrm{Ca}$ and $\mathrm{Pb}$ was endothermic when replacing exchangeable $\mathrm{K}$, which is consistent with literature for these cations (Deist and Talibudeen, 1967; Elkhatib et al., 1993; Laudelot et al., 1968; Maes and Cre mers, 1977; Parida et al., 1996; Rodda et al., 1996; Scheinost et al., 2001; Udo, 1978). Furthermore, heats for $\mathrm{K} / \mathrm{Pb}$ exchange were significantly smaller than those for $\mathrm{K} / \mathrm{Ca}$ exchange in both soils $(P \leq 0.1$ for Oxisol K/Ca and Ultisol $\mathrm{K} / \mathrm{Pb})$
TABLE 3

Heats of exchange $\left(\Delta \mathrm{H} ; \mathrm{kJ} \mathrm{mol}_{\mathrm{C}}{ }^{-1}\right)$ for the Oxisol and the Ultisol

\begin{tabular}{lcc}
\hline Soil & $\mathrm{K} / \mathrm{Ca}$ & $\mathrm{K} / \mathrm{Pb}$ \\
\hline Oxisol & $7.53(1.36) \mathrm{a}^{1,2}$ & $5.61(0.51) \mathrm{a}$ \\
Ultisol & $10.63(1.17) \mathrm{b}$ & $7.72(0.28) \mathrm{c}$ \\
\hline
\end{tabular}

${ }^{1}$ Numbers in parenthesis are standard deviations of the means.

${ }^{2}$ Means within a column or row with the same letter are not significantly different at $p<0.1$.

This means that more energy was absorbed from the surroundings when $\mathrm{Ca}$ replaced $\mathrm{K}$ than when $\mathrm{Pb}$ replaced $\mathrm{K}$. This was most likely because $\mathrm{Pb}$ has a lower hydration energy and a higher hy drated charge density than $\mathrm{Ca}$, facilitating the re placement of $\mathrm{K}$.

Heats of exchange were significantly greater $(P \leq 0.1)$ for the Ultisol than for the Oxisol. This indicates that both $\mathrm{Ca}$ and $\mathrm{Pb}$ required more en ergy to displace exchangeable $\mathrm{K}$ in the Ultisol than in the Oxisol. This was most likely caused by the presence of smectite in the Ultisol, which was not present in the Oxisol. This mineral tends to hold onto $\mathrm{K}$ tightly in its interlayer and most likely contributed to greater binding energy for $\mathrm{K}$. In a thermodynamic study looking at $\mathrm{K} / \mathrm{Ca}$ exchange in two soils, Sparks and Jardine (1981) found that the binding energy of $\mathrm{K}$ was greater in the soil having more interlayer surface charge.

The heats measured by calorimetry corre spond to the enthalpy change for the experimen tal conditions used and not to standard state conditions. To convert the calorimetric $\Delta \mathrm{H}$ to standard state conditions, $\Delta \mathrm{H}^{\circ}$, requires correct ing for the enthalpies associated with taking the clay/electrolyte systems to a state of infinite dilu tion (Goulding, 1983). However, differences be tween $\Delta \mathrm{H}$ and $\Delta \mathrm{H}^{\circ}$ for ion exchange are usually small (<10\%) (Barrer et al., 1963; Goulding, 1983; Laudelot et al., 1968).

In previous works, the $\Delta \mathrm{H}^{\circ}$ for $\mathrm{K} / \mathrm{Ca}$ ex change on a variety of soils ranged from 3.3 to $16.3 \mathrm{~kJ} \mathrm{~mol}_{\mathrm{C}}^{-1}$ (Deist and Talibudeen, 1967; Goulding and Talibudeen, 1984; Ogwada and Sparks, 1986; Sparks and Jardine, 1981), consistent with our values as measured by flow calorimetry. Most of these soils were dominated by 2:1 layer silicates, whereas the two soils used in this study were dominated by kaolinite and metal oxides. Reports of $\Delta \mathrm{H}$ or $\Delta \mathrm{H}^{\circ}$ for exchange on highly weathered soils dominated by kaolinite and ox ides are few. However, Udo (1978) reported a $\Delta \mathrm{H}^{\circ}$ of $54.5 \mathrm{~kJ} \mathrm{~mol}_{\mathrm{c}}{ }^{-1}$ for $\mathrm{K} / \mathrm{Ca}$ exchange on a 
kaolinitic soil clay that he derived from the tem perature dependence of $\ln \mathrm{K}$. Our Oxisol and Ultisol samples contained 56\% and 59\% clay, re spectively, of which about half was kaolinite. On a per gram of clay basis, the $\Delta \mathrm{H}$ for $\mathrm{K} / \mathrm{Ca}$ ex change on the Oxisol and Ultisol was 13.4 and $18.0 \mathrm{~kJ} \mathrm{molc}^{-1}$, respectively, considerably below the value reported by Udo (1978). To our knowl edge, Udo's value is considerably higher than any reported values for $\mathrm{K} / \mathrm{Ca}$ exchange. After look ing at Udo's data more carefully, however, we be lieve that an error may have been made when cal culating $\Delta \mathrm{H}^{\circ}$. We have reintegrated the $\ln \mathrm{K}_{\mathrm{c}}$ vs $\mathrm{X}_{\mathrm{K}}^{\prime}$ data in his Figure 2a, and then, using Udo's Equations (9) and (12), we calculated a $\Delta \mathrm{H}^{\circ}$ of about $15 \mathrm{~kJ} \mathrm{~mol}_{\mathrm{c}}^{-1}$, not the $54.5 \mathrm{~kJ} \mathrm{~mol}_{\mathrm{c}}{ }^{-1}$ orig inally reported. If our calculation is correct, Udo's enthalpy for $\mathrm{K} / \mathrm{Ca}$ exchange is consistent with what we and others have found.

The thermodynamics of $\mathrm{Pb}$ reactions in soils and mineral specimen clay have been studied much less extensively than reactions involving $\mathrm{Ca}$. In a Brazilian soil high in kaolinite and gibbsite, Airoldi and Critter (1997) found $\Delta \mathrm{H}^{\circ}$ for $\mathrm{Pb}$ ad

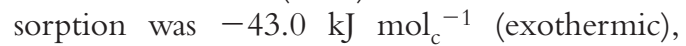
based on the temperature dependence of the Langmuir isotherm. Lopez et al. (1995) and Lopez Delgado et al. (1998) suggested that $\mathrm{Pb}$ ad sorption on blast furnace sludge, which was $47 \%$ and $34 \% \mathrm{Fe}_{2} \mathrm{O}_{3}$ and carbon, respectively, occurred at least, in part, via the replacement of $\mathrm{Ca}$ (pre sumably cation exchange) and found $\Delta \mathrm{H}^{\circ}$ was endothermic. Their value of $26.1 \pm 3.1 \mathrm{~kJ}$ $\mathrm{mol}_{\mathrm{C}}{ }^{-1}$ is about 10 times greater than our values for $\mathrm{Pb} / \mathrm{Ca}$ exchange, which were on the order of 2 to $3 \mathrm{~kJ} \mathrm{~mol}_{\mathrm{c}}^{-1}$ (Table 3 ). They did not partition the enthalpy change between ion exchange and specific adsorption. Rodda et al. (1996) deter mined that $\Delta \mathrm{H}^{\circ}$ for sorption of $\mathrm{Pb}$ on goethite at $\mathrm{pH} 5.5$ was $8.2 \pm 5.5 \mathrm{~kJ} \mathrm{~mol}_{\mathrm{c}}^{-1}$ using the tem perature dependence $\left(10^{\circ}\right.$ to $\left.70^{\circ} \mathrm{C}\right)$ of several sorption models (Langmuir two site, FDM sur face precipitation, and BET models). The goethite surface would have been positively charged at that $\mathrm{pH}(\mathrm{ZPC}=8.3)$, suggesting that specific adsorp tion was a primary mechanism for $\mathrm{Pb}$ adsorption.

\section{Differential Heats of Adsorption}

The CEC of the Oxisol and Ultisol depended on the cation used to saturate the exchange sites (Table 4). The CEC followed the order Ca satu rated $>\mathrm{Pb}$ saturated $>\mathrm{K}$ saturated. Deist and Talibudeen (1967), Maes and Cremers (1977), and Rhue and Mansell (1988) found higher measured CECs with divalent cations compared with
TABLE 4

CEC of the Oxisol and Ultisol as a function of the saturating cation

\begin{tabular}{lrrr}
\hline \multirow{2}{*}{ Soil } & \multicolumn{1}{c}{$\mathrm{Ca}$} & $\mathrm{Pb}$ & $\mathrm{K}$ \\
\cline { 2 - 4 } & \multicolumn{1}{c}{$\mathrm{ymol}_{\mathrm{c}} \mathrm{kg}^{-1}$} & \\
\hline Oxisol & $60.0(2.3)^{1}$ & $42.5(0.7)$ & $28.1(4.0)$ \\
Ultisol & $129.6(6.6)$ & $112.3(2.4)$ & $97.9(6.1)$ \\
\hline
\end{tabular}

${ }^{1}$ Numbers in parenthesis are standard deviations of the means.

monovalent ones. Lower CEC is caused, at least in part, by a failure to take $\mathrm{H}^{+}$into account in the ion exchange process. $\mathrm{pH}$ changes that we have measured in column effluent during $\mathrm{K} / \mathrm{Ca}$ ex change are consistent with a K/H/Ca ternary ex change reaction in these soils (data not shown). In addition, speciation calculations performed by Vi sual Minteq (Gustafsson, 2002) showed that $8 \%$ of the total $\mathrm{Pb}$ was present as $\mathrm{PbNO}_{3}{ }^{+}$, whereas less than $2 \%$ of the total $\mathrm{Ca}$ was present as $\mathrm{CaNO}_{3}{ }^{+}$. The higher amount of the monovalent $\mathrm{PbNO}_{3}{ }^{+}$ relative to $\mathrm{CaNO}_{3}{ }^{+}$in the respective systems may also have contributed to the lower apparent CEC when comparing $\mathrm{Pb}$ with $\mathrm{Ca}$.

By equilibrating soil with the various $\mathrm{K}^{+}+$ $\mathrm{M}^{2+}$ solutions, the concentration of exchange able divalent cation was stepped incrementally from zero up to the values shown in Table 4 cor responding to $5 \mathrm{mM} \mathrm{M} \mathrm{M}^{2+}$. Integral heats of ex change at each concentration step are plotted against the concentration of divalent cation on the exchanger in Figs. $1 \mathrm{a}$ and $\mathrm{b}$ and $2 \mathrm{a}$ and $\mathrm{b}$. Smooth curves were fitted through the data points using a least squares analysis procedure.

The relationship between the heat of ex change and the concentration of exchangeable $\mathrm{Ca}$ or $\mathrm{Pb}$ for the Oxisol (Fig. 1a,b) was linear, with $R^{2}$ equal to 0.97 and 0.94 , respectively. Differentia tion of the linear equations in Figs. $1 \mathrm{a}$ and $\mathrm{b}$ pro vided the differential heats of exchange, which are plotted in Figs. 1c and d. The constant values for the differential heats of exchange for $\mathrm{Pb}$ and $\mathrm{Ca}$ indicate that as the exchange sites in the Oxisol became increasingly $\mathrm{Ca}$ or $\mathrm{Pb}$ saturated, the en ergy required to replace the remaining $\mathrm{K}$ did not change. Thus, the exchange sites were energeti cally homogeneous in the Oxisol. The main com ponents capable of cation exchange at the $\mathrm{pH}$ of the experiment $(\mathrm{pH}=4.7)$ were organic matter and kaolinite (ZPCs $<3$ and 3 to 5, respectively; Braggs et al., 1994; Ferris and Jepson 1975; Sparks, 1995). Both materials have external cation ex 

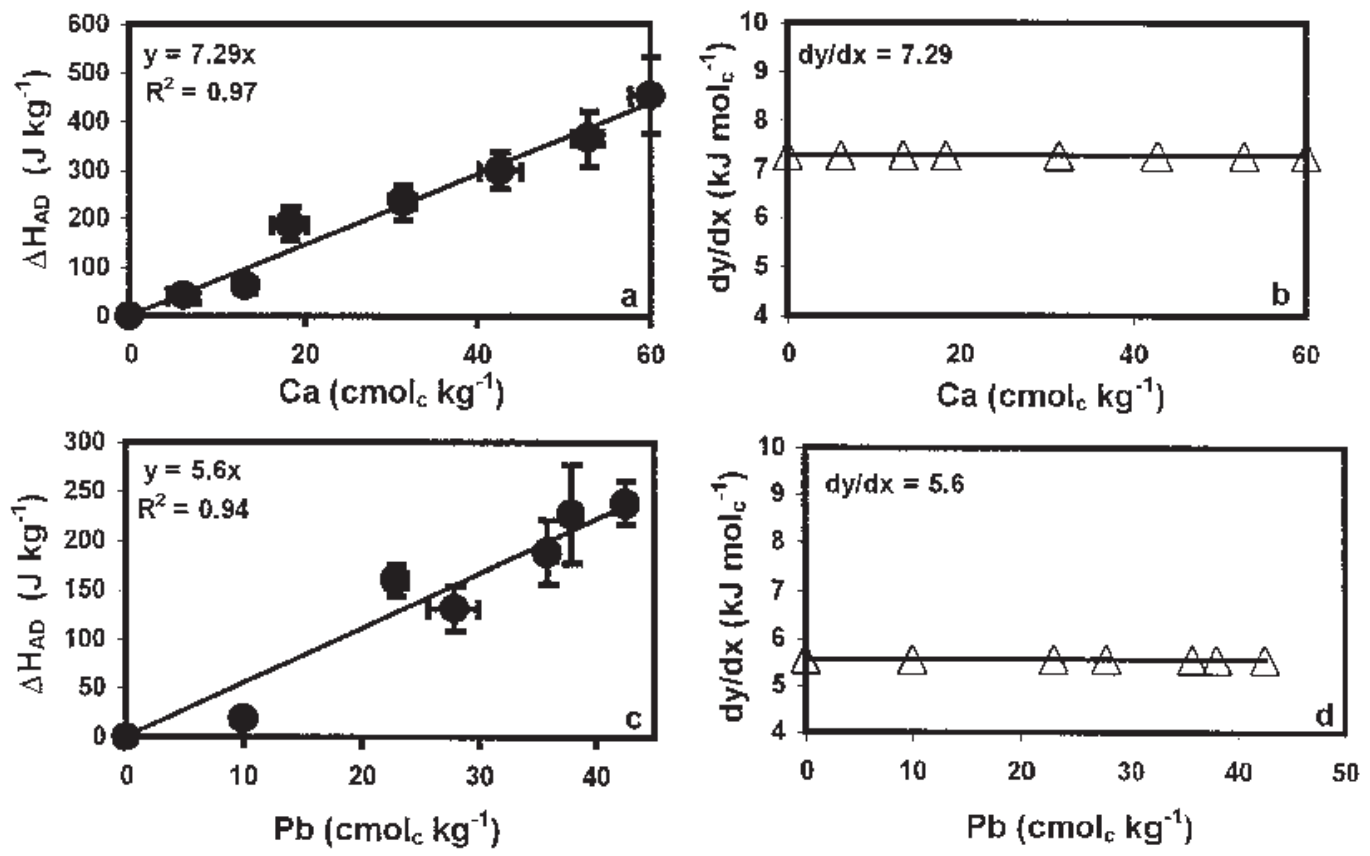

Fig. 1. Integral $(a, b)$ and differential $(c, d)$ heats of exchange for $\mathrm{Ca}$ and $\mathrm{Pb}$ on Oxisol.

change sites, which may exhibit constant affinities for $\mathrm{K}$ as exchangeable $\mathrm{K}$ content varies. The other major components capable of ion exchange in this soil were gibbsite, goethite, and amorphous Fe and $\mathrm{Al}$ oxides, which should have been positively charged at $\mathrm{pH} 4.7$ and, thus, incapable of signifi cant cation exchange (ZPCs of gibbsite and goethite 5.0 to 9.0 and 7.8 to 9.0 , respectively; Sparks, 1995; Su and Suarez, 1997).

For the Ultisol, a quadratic equation best de scribed the relation between the integral heats of exchange and concentration of exchangeable $\mathrm{Ca}$ or $\mathrm{Pb}$ (Fig. $2 \mathrm{a}$ and $\mathrm{b}$ ) which, when differentiated, yielded the plots in Fig. $2 \mathrm{c}$ and d. The exchange sites in this soil showed evidence of heterogene ity in that an increasing amount of energy was re quired to remove exchangeable $\mathrm{K}$ as the amount of exchangeable $\mathrm{K}$ decreased.

An important difference between the Ultisol and the Oxisol is the presence of smectite in the former (Table 1). As indicated previously, 2:1 layer silicates generally exhibit high selectivity for $\mathrm{K}$ relative to $\mathrm{Ca}$ in the interlayer. The observed surface heterogeneity can be explained if initially $\mathrm{Ca}$ and $\mathrm{Pb}$ replaced $\mathrm{K}$ adsorbed to external ex change sites (i.e., organic matter, kaolinite, edges and planar smectitic surfaces) and then proceeded to replace $\mathrm{K}$ from the smectite interlayers, the lat ter requiring more energy (Gast, 1972; Sparks and Jardine, 1981). Results obtained from X ray dif fraction analysis support this hypothesis since the smectite in the Ultisol was able to collapse, in part, when $\mathrm{K}$ saturated but re expanded on $\mathrm{Ca}$ saturation. The $\mathrm{d}$ spacings for the $\mathrm{Ca}$ saturated smectite were $1.472 \mathrm{~nm}$ both before and after $\mathrm{K}$ saturation; the $\mathrm{d}$ spacing for the $\mathrm{K}$ saturated smectite was $1.404 \mathrm{~nm}$.

\section{SUMMARY AND CONCLUSIONS}

Lead was adsorbed specifically in both soils. The Oxisol had between 3000 and $3500 \mathrm{mg} \mathrm{kg}^{-1}$ nonexchangeable $\mathrm{Pb}$ whereas that value for the Ultisol was about $1900 \mathrm{mg} \mathrm{kg}^{-1}$. Specific adsorp tion of $\mathrm{Pb}$ was found to be driven predominantly by a change in entropy inasmuch as there was no detectable heat associated with this reaction.

Flow calorimetry was used to measure the heat associated with $\mathrm{K} / \mathrm{Ca}$ and $\mathrm{K} / \mathrm{Pb}$ exchange in these two soils. The heat of reaction provided in formation about the binding strength of these cations to soil surfaces. The adsorption of $\mathrm{Ca}$ and $\mathrm{Pb}$, when replacing exchangeable $\mathrm{K}$, was en dothermic. The heats of exchange were smaller for $\mathrm{Pb}$ than for $\mathrm{Ca}$ on both soils, indicating that 

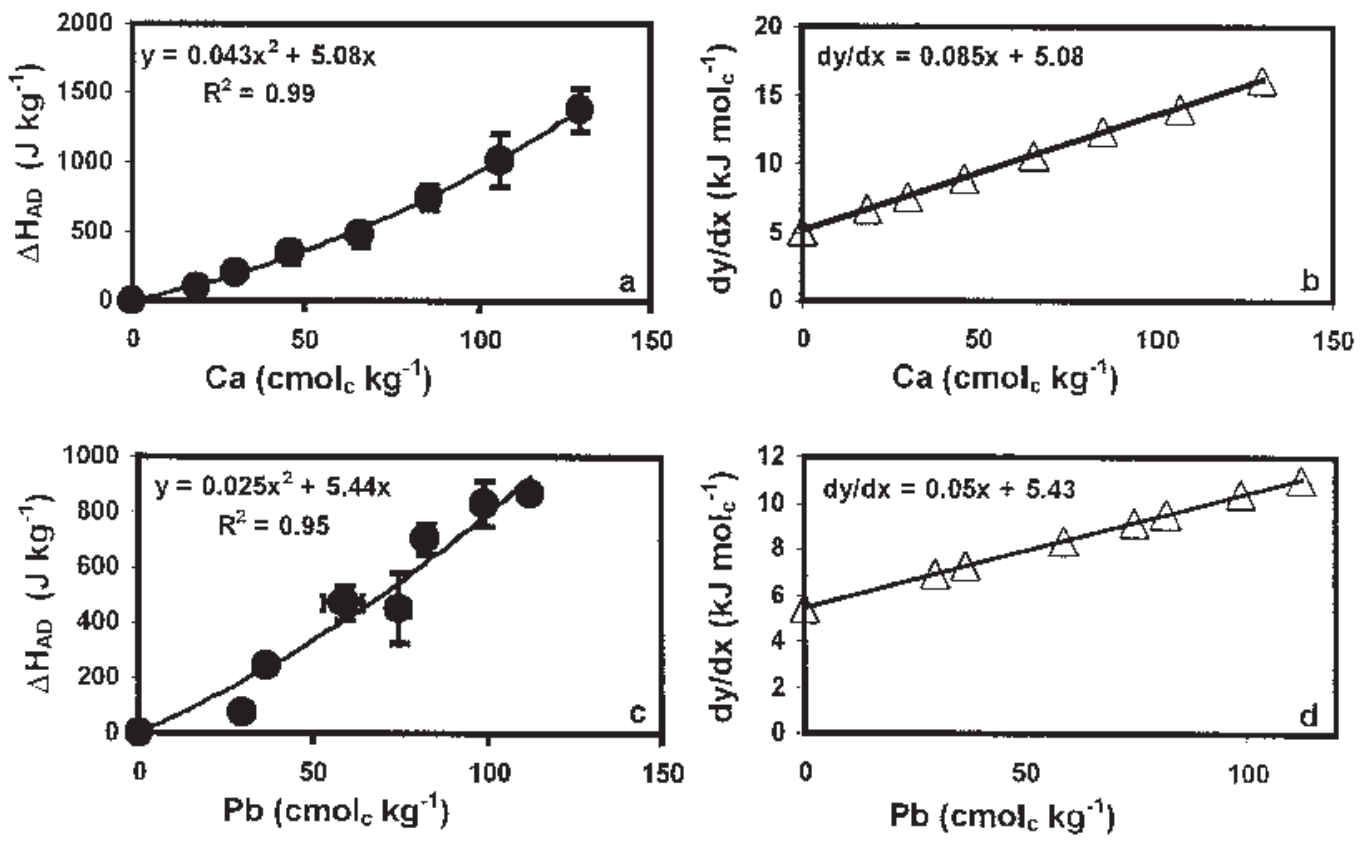

Fig. 2. Integral $(a, b)$ and differential $(c, d)$ heats of exchange for $\mathrm{Ca}$ and $\mathrm{Pb}$ on Ultisol.

more energy was required for $\mathrm{Ca}$ to replace $\mathrm{K}$ than for $\mathrm{Pb}$ to replace $\mathrm{K}$ from soil surfaces. As di valent cation saturation of the Oxisol increased, there was no change in the amount of heat re quired to replace the remaining $\mathrm{K}$, indicating that exchange sites were energetically similar in this soil. However, it took an increasing amount of energy to remove exchangeable $\mathrm{K}$ as the amount of exchangeable $\mathrm{K}$ decreased in the Ultisol. Dif ferences between the two soils were attributed to smectite, which was present in the clay fraction of the Ultisol but not in the Oxisol.

\section{REFERENCES}

Airoldi, C., and S. A. M. Critter. 1997. Brazilian red Latosol a typic soil as an exchanger: A thermody namic study involving $\mathrm{Cu}, \mathrm{Zn}, \mathrm{Cd}, \mathrm{Hg}, \mathrm{Pb}, \mathrm{Ca}$ and Na. Clays Clay Miner. 45:125 131.

Appel, C., and L. Ma. 2002. Concentration, pH, and surface charge effects on $\mathrm{Cd}$ and $\mathrm{Pb}$ sorption in three tropical soils. J. Environ. Qual. 31:581 589.

Bargar, J. R., G. E. Brown, and G. A. Parks. 1997a. Sur face complexation of $\mathrm{Pb}$ (II) at oxide water inter faces: I. XAFS and bond valence determination of mononuclear and polynuclear $\mathrm{Pb}$ (II) sorption products on aluminum oxides. Geochim. Cos mochim. Acta 61:2617 2637.

Bargar, J. R., G. E. Brown, and G. A. Parks. 1997b. Sur face complexation of $\mathrm{Pb}$ (II) at oxide water inter faces: II. XAFS and bond valence determination of mononuclear $\mathrm{Pb}$ (II) sorption products and surface functional groups on iron oxides. Geochim. Cos mochim. Acta 61:2639 2652.

Bargar, J. R., G. E. Brown, and G. A. Parks. 1998. Sur face complexation of $\mathrm{Pb}(\mathrm{II})$ at oxide water inter faces: III. XAFS determination of $\mathrm{Pb}$ (II) and $\mathrm{Pb}$ (II) chloro complexes on goethite and alumina. Geochim. Cosmochim. Acta 62:193 207.

Barrer, R. M., D.J. Ward, and L.V.C. Rees. 1963. Ther mochemistry and thermodynamics of ion ex change in a crystalline exchange medium. Proc. R. Soc. London Ser. A Math. 273:180 197.

Braggs, B., D. Fornasiero, J. Ralston, and R. S. Smart. 1994. The effect of surface modification by an organosilane on the electrochemical properties of kaolinite. Clays Clay Miner. 42:123 136.

Bruemmer, G. W., J. Gerth, and U. Herms. 1986. Heavy metal species, mobility, and availability in soils. Z. Pflanzenernaegr. Bodenk. 149:382 398.

Brown, G. E., A. L. Foster, and J. D. Ostergren. 1999. Mineral surfaces and bioavailability of heavy met als: A molecular scale perspective. Proc. Natl. Acad. Sci. USA 96:3388 3395.

Davis, J. A., and J. O. Leckie. 1978. Surface ionization and complexation at the oxide/water interface. II. Surface properties of amorphous iron oxyhydrox ide and adsorption of metals. J. Colloid Interface Sci. 67:90 107. 
Deist, J., and O. Talibudeen. 1967. Thermodynamics of K Ca exchange in soils. J. Soil Sci. 18:138 148.

Eick, M. J., J. D. Peak, P. V. Brady, and J. D. Pesek. 1999. Kinetics of lead adsorption/desorption on goethite: Residence time effect. Soil Sci. 164:28 39.

Elkhatib, E. A., G. M. Elshebiny, G. M. Elsubruiti, and A. M. Balba. 1993. Thermodynamics of lead sorp tion and desorption in soils. Z. Pflanzenernaegr. Bodenk. 156:461 465.

Ferris, A. P., and W. B. Jepson. 1975. The exchange ca pacities of kaolinite and the preparation of ho moionic clays. J. Colloid Interface Sci. 51:245 259.

Forbes, E. A., A. M. Posner, and J. P. Quirk. 1976. The specific adsorption of divalent $\mathrm{Cd}, \mathrm{Co}, \mathrm{Cu}, \mathrm{Pb}$, and Zn on goethite. J. Soil Sci. 27:154 166.

Gao, S. A., W. J. Walker, R. A. Dahlgren, and J. Bold. 1997. Simultaneous sorption of Cd, Cu, Ni, Zn, Pb, and $\mathrm{Cr}$ on soils treated with sewage sludge super natant. Water Air Soil Pollut. 93:331 345.

Gast, R. G. 1972. Alkali metal cation exchange on Chambers montmorillonite. Soil Sci. Soc. Am. Proc. 36:14 19.

Gast, R. G., R. V. Bladel, and K. B. Deshpande. 1969. Standard heats and entropies of exchange for alkali metal cations on Wyoming bentonite. Soil Sci. Soc. Am. Proc. 33:661 664.

Gong, C. R., and R. J. Donahoe. 1997. An experimen tal study of heavy metal attenuation and mobility in sandy loam soils. Appl. Geochem. 12:243 254.

Goulding, K. 1983. Thermodynamics and potassium exchange in soils and clay minerals. In Advances in Agronomy, vol. 36. N.C. Brady (ed.). Academic Press, New York, pp. 215264.

Goulding, K. W. T., and O. Talibudeen. 1984. Ther modynamics of $\mathrm{K} \mathrm{Ca}$ exchange in soils. II. Effects of mineralogy, residual $\mathrm{K}$ and $\mathrm{pH}$ in soils from long term ADAS experiments. J. Soil Sci. 35:409 420.

Gustafsson, J. P. 2002. Visual Minteq [Online]. Avail able at http://www.lwr.kth. se/english/OurSoft ware/Vminteq/\#download (verified 6 Aug. 2002).

Huheey, J. E. 1983. Inorganic Chemistry: Principles of Structure and Reactivity, 3rd Ed. Harper and Row, San Francisco, CA.

Jenne, E. A. 1968. Controls on $\mathrm{Mn}, \mathrm{Fe}, \mathrm{Co}, \mathrm{Ni}, \mathrm{Cu}$, and $\mathrm{Zn}$ concentrations in soils and waters The domi nant role of hydrous manganese and iron oxides. Adv. Chem. Ser. 73:337 387.

Kinniburgh, D. G., M. L. Jackson, and J. K. Sayers. 1976. Adsorption of alkaline earth, transition and heavy metal cations by hydrous oxide gels of iron and alu minum. Soil Sci. Soc. Am. J. 40:796 799.

Laudelot, H., R. V. Bladel, G. H. Bolt, and A. L. Page. 1968. Thermodynamics of heterovalent cation ex change reactions in a montmorillonite clay. Trans. Faraday Soc. 64:1477 1488.

Lopez, F. A., C. Perez, E. Sainz, and M. Alonso. 1995. Adsorption of $\mathrm{Pb} 2+$ on blast furnace sludge. $\mathrm{J}$. Chem. Technol. Biotechnol. 62:200 206.

Lopez Delgado, A., C. Perez, and F. A. Lopez. 1998.
Sorption of heavy metals on blast furnace sludge. Water Res. 32:989 996.

Maes, A., and A. Cremers. 1977. Charge density effects in ion exchange. Part 1. Heterovalent exchange equilibria. J. Chem. Soc. Faraday Trans. 1.73:1807 1814.

McBride, M. B. 1994. Environmental Chemistry in Soils. Oxford University Press, Oxford, UK.

Nriagu, J. O. 1998. Paleoenvironmental research Tales told in lead. Science 281:1622 1623.

Ogwada, R. A., and D. L. Sparks. 1986. A critical eval uation on the use of kinetics for determining ther modynamics of ion exchange in soils. Soil Sci. Soc. Am. J. 50:300 305.

Pardo, M. T. 2000. Sorption of lead, copper, zinc, and cadmium by soils: Effect of nitriloacetic acid on metal retention. Commun. Soil Sci. Plant Anal. 31:31 40.

Parida, K., P. K. Satapathy, and N. Das. 1996. Studies on Indian Ocean manganese nodules. 4. Adsorption of some bivalent heavy metal ions onto ferroman ganese nodules. J. Colloid Interface Sci. 181:456 462.

Phillips, I. R. 1999. Copper, lead, cadmium, and zinc sorption by waterlogged and air dry soil. J. Soil Contam. 8:343 364.

Rhue, R. D., C. Appel, and N. Kabengi. 2002. Measur ing surface chemical properties of soil using flow calorimetry. Soil Sci.(in press).

Rhue, R. D., and R. S. Mansell. 1988. The effect of $\mathrm{pH}$ on sodium calcium and potassium calcium ex change selectivity for Cecil soil. Soil Sci. Soc. Am. J. 52:641 647.

Rodda, D. P., B. B. Johnson, and J. D. Wells. 1996. Mod eling the effect of temperature on adsorption of lead(II) and zinc(II) onto goethite at constant $\mathrm{pH}$. J. Colloid Interface Sci. 184:365 377.

Sauve, S., C. E. Martinez, M. McBride, and W. Hen dershot. 2000. Adsorption of free lead $\left(\mathrm{Pb}^{2+}\right)$ by pedogenic oxides, ferrihydrite, and leaf compost. Soil Sci. Soc. Am. J. 64:595 599.

Sauve, S., M. McBride, and W. H. Hendershot. 1998. Soil solution speciation of lead (II): Effects of or ganic matter and pH. Soil Sci. Soc. Am. J. 62:618 621.

Scheinost, A. C., S. Abend, K. I. Pandya, and D. L. Sparks. 2001. Kinetic controls on $\mathrm{Cu}$ and $\mathrm{Pb}$ sorp tion by ferrihydrite. Environ. Sci. Technol. 35: 10901096.

Sparks, D. L. 1995. Environmental Soil Chemistry. Aca demic Press, New York.

Sparks, D. L., and P. M. Jardine. 1981. Thermodynam ics of potassium exchange in soil using a kinetics approach. Soil Sci. Soc. Am. J. 45:1094 1099.

Strawn, D. G., A. M. Scheidegger, and D. L. Sparks. 1998. Kinetics and mechanisms of $\mathrm{Pb}(\mathrm{II})$ sorption and desorption at the aluminum oxide water inter face. Environ. Sci. Technol. 32:2596 2601.

Strawn, D. G., and D. L. Sparks. 1999. The use of XAFS to distinguish between inner and outer sphere 
lead adsorption complexes on montmorillonite. J. Colloid Interface Sci. 216:257 269.

Su, C. M., and D. L. Suarez. 1997. In situ infrared spe ciation of absorbed carbonate on aluminum and iron oxide. Clays Clay Miner. 45:814 825.

Udo, E. J. 1978. Thermodynamics of potassium cal cium and magnesium calcium exchange reactions on kaolinitic soil clay. Soil Sci. Soc. Am. J. 42: 556560 .

Uehara, G., and G. P. Gillman. 1981. The Mineralogy, Chemistry and Physics of Tropical Soils with Vari able Charge Clays. Westview Press, Boulder, CO.

U.S. Environmental Protection Agency. USEPA. 1996.
Soil screening guidance: Technical background document. EPA/540/R 95/128. U.S. Govt. Print. Office, Washington, DC.

van Olphen, H. 1977. An Introduction to Clay Col loid Chemistry, 2nd Ed. John Wiley \& Sons, New York.

Xia, K., W. Bleam, and P.A. Helmke. 1997. Studies of the nature of $\mathrm{Cu}^{2+}$ and $\mathrm{Pb}^{2+}$ binding sites in soil humic substances using $\mathrm{X}$ ray absorption spectroscopy. Geochim. Cosmochim. Acta 61:2211 2221.

Zhang, M.,A. K. Alva, Y. C. Li, and D. V. Calvert. 1997. Chemical association of $\mathrm{Cu}, \mathrm{Zn}, \mathrm{Mn}$, and $\mathrm{Pb}$ in se lected sandy citrus soils. Soil Sci. 162:181 188. 